\title{
Study of Reptile and Amphibian Diversity at Ledok Amprong Poncokusumo, Malang East Java
}

\author{
Luhur Septiadi $^{1)^{*}}$, Berry Fakhry Hanifa ${ }^{1)}$, Ainul Khatimah ${ }^{1)}$, Yunita Indawati ${ }^{1)}$, Muhammad Zakaria Alwi ${ }^{1)}$, \\ Muhammad Prayogi Erfanda \\ ${ }^{1)}$ Department of Biology, State Islamic University of Maulana Malik Ibrahim Malang, Jl. Gajayana No.50, Malang, \\ Indonesia \\ ${ }^{*}$ Email: luhur.septiadi@gmail.com
}

\begin{abstract}
Malang is one of the areas that have a high diversity of reptiles and amphibians because of the strategic ecosystem but still minimal in terms of research publications. The purpose of this study was to know the diversity of reptiles and amphibian through the existence of herpetofauna species, microhabitat and indicator species. Data was collected during the rainy season, once a month in the period of three months from October 2017 to January 2018 at night. Data collection was conducted using the Virtual Encounter Survey method with different zones and limited by time. The collected specimens were identified with the guidance of literatures. The collected specimens were then preserved at the Animal Physiology Laboratory, Department of Biology, State Islamic University of Maulana Malik Ibrahim Malang. Then, the data was analyzed to obtain the diversity index, frequency and dominance. The result showed that the number of reptiles found in the location site was seven species consisting of Famili Gekkonidae, Scincidae, Agamidae and Elapidae. Mean while for the species of amphibians, it was obtained nine species consisting of Famili Bufonidae, Ranidae, Rhacophoridae, Dicroglossidae, and Microhylidae. The ecosystem consisted of four habitat types including terrestrial, arboreal, semi-aquatic and aquatic. However, based on the value of diversity index, relative frequency, and dominance value, as well as the indicator species, this area has a relatively low diversity, the disturbed environment and therefore conservation efforts need to be undertaken.
\end{abstract}

Keywords: amphibians, reptiles, diversity, Ledok Amprong, Indonesia

\section{Studi Keanekaragaman Reptil dan Amfibi di Lokasi Wisata Ledok Amprong Poncokusumo, Malang, Jawa Timur}

\author{
Luhur Septiadi $^{1{ }^{*}}$, Berry Fakhry Hanifa ${ }^{1)}$, Ainul Khatimah ${ }^{1)}$, Yunita Indawati ${ }^{1)}$, Muhammad Zakaria Alwi ${ }^{1)}$, \\ Muhammad Prayogi Erfanda \\ ${ }^{1)}$ Jurusan Biologi, Universitas Islam Negeri Maulana Malik Ibrahim Malang, Jl. Gajayana No.50, Malang, Indonesia
}

${ }^{*}$ Alamat korespondensi: luhur.septiadi@gmail.com

\begin{abstract}
ABSTRAK
Malang merupakan salah satu wilayah yang memiliki potensi keanekaragaman hewan reptil dan amfibi karena ekosistemnya yang strategis namun masih minim dalam hal publikasi penelitian. Penelitian ini bertujuan untuk mengetahui keanekaragaman jenis reptil dan amfibi melalui keberadaan jenis reptil dan amfibi, mikrohabitat dan spesies bioindikator lingkungannya. Pengambilan data dilakukan satu bulan sekali dalam kurun waktu tiga bulan sejak bulan Oktober 2017 hingga Januari 2018 saat musim hujan ketika malam hari. Pengambilan data dilakukan dengan menggunakan metode Virtual Encounter Survey dengan zonasi yang berbeda dan dibatasi oleh waktu. Spesimen yang dikoleksi, diidentifikasi, kemudian diawetkan di Laboratorium Fisiologi Hewan, Jurusan Biologi, Universitas Islam Negeri Maulana Malik Ibrahim Malang. Hasil data yang didapat kemudian dianalisis untuk diketahui indeks diversitas, frekuensi relatif, dan dominansi. Hasil analisis data diketahui bahwa jumlah jenis reptil yang ditemukan sejumlah tujuh spesies yang terdiri dari Famili Gekkonidae, Scincidae, Agamidae dan Elapidae. Sedangkan untuk jenis amfibi, didapatkan sebanyak sembilan spesies yang terdiri dari Famili Bufonidae, Ranidae, Rhacophoridae, Dicroglossidae, dan Microhylidae. Ekosistemnya tersusun atas empat tipe habitat diantaranya terrestrial, arboreal, semi-akuatik dan akuatik. Namun berdasarkan nilai indeks diversitas, frekuensi relatif, dan nilai dominansi, serta keberadaan spesies indikator, menunjukkan
\end{abstract}


bahwa wilayah ini memiliki keanekaragaman yang relatif rendah, lingkungan yang terganggu dan perlu dilakukan upaya konservasi.

Kata kunci: amfibia, reptil, keanekaragaman, ledok amprong, Indonesia

\section{INTRODUCTION}

Malang is one of the areas with an area of $3,534.86 \mathrm{~km}^{2}$ flanked by several rows of mountains and various rivers that cause a strategic ecosystem for this region [1]. This causes the high potential of biodiversity in the species of flora and fauna that are interesting and also endemic, but still minimal in terms of research publications. One of the areas in Malang that has the potential of biodiversity is Bromo Tengger Semeru National Park (TNBTS).

Bromo Tengger Semeru National Park (TNBTS) is a cluster of mountains that is flooded by Brantas River which comes from Amprong River, into Semeru Mountain [2]. This area is a tourist attraction especially for hiking activities, rafting, and river tubing. These activities can affect the sustainability of the ecosystem, including the biodiversity of species in the area.

The Southwestern border of the TNBTS area, there is a flow that originates from Coban Pelangi which is used as a river tubbing but rarely operates, namely Ledok Amprong Nature Tourism $(-8.032196,112.828178)$ with an altitude of \pm 800 meters above sea level. This area is dominated by permanent buildings for stays, watercress farms along the right and left of the river and several locations that have been used by the community as production forests. Some areas are also overgrown with naturally dense vegetation dominated by shrubs, bamboo, and ferns. A clear flow of water, suitable temperature, and humidity with various types of habitat, can support the existence of various herpetofauna species.

Herpetofauna is a group of fauna that includes reptiles and amphibians that can be used as the bioindicator for a diversity of species that is currently still not realized yet. Herpetofauna has an important role in taxonomic studies as the key to understanding the existing biodiversity, as well as the ecology in knowing the balance and sustainability of its ecosystem [3]. The data obtained can also be used as an early marker of ecosystem changes [4]. The purpose of this research was to know the diversity of reptile and amphibian species at Ledok Amprong, Poncokusumo, Malang, East Java.

\section{RESEARCH METHOD}

The specimens studied were all types of reptiles and amphibians. Data retrieval was done once a month within three months from October 2017 to January 2018 during the rainy season. The research location was located at the river tubing Ledok Amprong Poncokusumo, Malang, East Java.

The method used was Visual Encounter Survey (VES), which was conducted at night along the river and tourist sites with a time limit of four hours of data collection [5, 6, 7]. During sampling, three sampling groups were classified according to habitat type with the same area. The first group searched the area around parks, cottage, stalls and path routes (Zone 1). The second group searched the stream and the right-left bank of the river (Zone 2). The third group searched the rice fields and around it (Zone 3).

The specimens were later captured, identified, recorded the location, time of capture and then documented. Voucher specimens were taken, while other specimens were released back into their habitat [7]

The specimen voucher was then preserved at the Animal Physiology Laboratory, Department of Biology, Maulana Malik Ibrahim State Islamic University of Malang. Identification of amphibians based on literature as well as reptile identification based on literature $[3,8,9,10]$.

The results of the data were analyzed using Shanon-Weiner diversity index, Simpson's fairness index, Margalef of species richness index, dominance [11] and relative frequency to determine the diversity. 


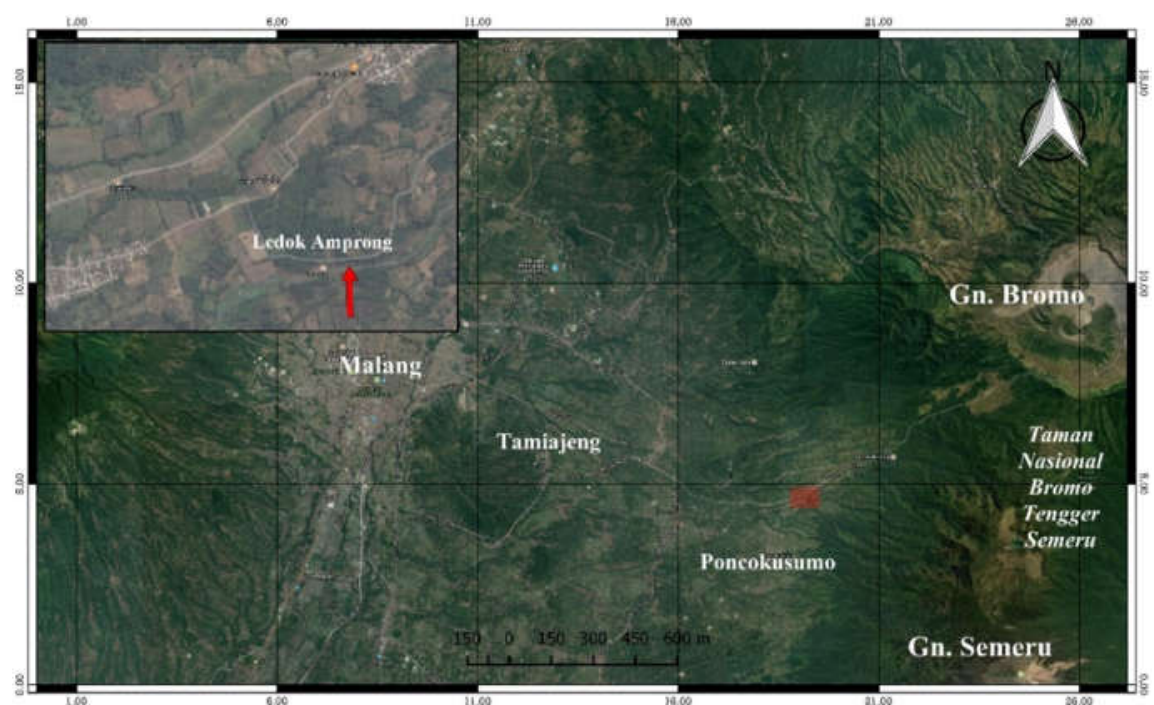

Figure 1. Study location of Ledok Amprong tourism

\section{RESULTS AND DISCUSSION}

Amphibian and reptile diversity analysis at Ledok Amprong tourism site. The diversity analysis of amphibian and reptile species found in Ledok Amprong tourism sites as a whole area has an index value of 2.203 indicating that species diversity at Ledok Amprong tourism sites was moderate (Table 3). According to Odum [11], if $H^{\prime}<1$, then the diversity is low, $\mathrm{H}^{\prime} 1-3$, then the diversity is moderate, and $\mathrm{H}^{\prime}>3$, then diversity is high.

The value of dominance at Ledok Amprong tourism sites was 0.150 , which means that dominance was low (Table 2). If the value of $\mathrm{D}$ is $0.01-0.30$ then the dominance is low, if the value of $\mathrm{D}$ is 0.31 0.60 then the dominance is moderate, and if the value of $\mathrm{D} 0.61-1.0$ then the dominance is high [17].

The Evenness Index of species at the Ledok Amprong tourism site shows a value of 0.565 , which means that the fairness of the species was likely to be depressed by the environment (Table 2).

The fairness index value ranges from $0-1$ tends to be depressed by the environment. If the value of $\mathrm{E}<0.20$, it can be concluded that the distribution of the species is unstable, whereas if the value $\mathrm{E} 0.21<\mathrm{E}<1$, it can be indicated the distribution of species is stable
[18]. Index of species richness obtained the value of 3.179 which means species richness in tourist sites Ledok Amprong fairly moderate (Table 2). Based on criteria by Hill [17], if R $<2.5$, it indicates a low level of species richness, if it shows $2.5>\mathrm{R}>4$ it indicates a moderate level of species richness, and if it shows $\mathrm{R}>4$, it indicates a high level of Species richness.

The calculation of diversity index showed that the diversity in zones 1,2 , and 3 , was $1.776,1.359,1.121$, repectively (Table 3 ), have moderate diversity. Krebs [18], if the index shows 1-3 values then diversity is moderate. As for the value of evenness the three zones tend to be depressed environment. If the criteria of fairness index value ranges from $0-1$ it can be indicated that the region tends to be depressed [18]. The dominance of species in each zone (Table 3), in zone 1 can be concluded of low species dominance, while for zone 2 and 3 is moderate, with the calculation of 0.3444 and 0.493 . If $\mathrm{D} 0.01-0.30$, then the dominance was low, $0.31-0.60$, then the dominance was medium and D $0.61-1.0$, then the dominance was high. The Margalef index shows that the three zones indicated a low level of species richness (Table 3 ), since the species richness value is less than 2.5 [17].

The results of the relative frequency analysis of the three types of zonation (Table 
Table 1. Diversity of reptile and amphibians found in Ledok Amprong tourism site

\begin{tabular}{|c|c|c|c|c|c|c|c|}
\hline \multicolumn{2}{|c|}{ Herpetofauna } & \multirow{2}{*}{ Habitat } & \multirow{2}{*}{ IUCN } & \multicolumn{3}{|c|}{ Sampling } & \multirow{2}{*}{$\sum_{\text {Individual }}$} \\
\hline Family & Species & & & 1 & 2 & 3 & \\
\hline Bufonidae & Duttaphrynus melanostictus & Terrestrial & $\mathrm{LC}$ & $\checkmark$ & $\checkmark$ & $\checkmark$ & 17 \\
\hline Rhacoporidae & Polypedates leucomystax & Arboreal & $\mathrm{LC}$ & $\checkmark$ & $\checkmark$ & $\checkmark$ & 7 \\
\hline \multirow[t]{3}{*}{ Ranidae } & Chalcorana chalconota & Semi-aquatic & $\mathrm{LC}$ & $\checkmark$ & $\checkmark$ & $\checkmark$ & 23 \\
\hline & Huia masonii* & Aquatic & VU & $\checkmark$ & $\checkmark$ & $\checkmark$ & 7 \\
\hline & Odorrana hosii & Semi-aquatic & $\mathrm{LC}$ & $\checkmark$ & $\checkmark$ & $\checkmark$ & 3 \\
\hline \multirow[t]{2}{*}{ Dicroglossidae } & Fejervarya limnocharis & Semi-aquatic & $\mathrm{LC}$ & $\checkmark$ & - & - & 1 \\
\hline & Occydoziga lima & Aquatic & $\mathrm{LC}$ & $\checkmark$ & $\checkmark$ & $\checkmark$ & 29 \\
\hline Megophyridae & Leptobrachium haseltii & Terrestrial & $\mathrm{LC}$ & - & $\checkmark$ & - & 1 \\
\hline Microhylidae & Microhyla achatina & Terrestrial & $\mathrm{LC}$ & - & - & $\checkmark$ & 1 \\
\hline Scincidae & Eutropis multifasciata & Terrestrial & $\mathrm{LC}$ & $\checkmark$ & $\checkmark$ & $\sqrt{ }$ & 3 \\
\hline \multirow[t]{4}{*}{ Gekkonidae } & Hemidactylus frenatus & Terrestrial & $\mathrm{LC}$ & - & $\checkmark$ & $\checkmark$ & 9 \\
\hline & Cyrtodactylus marmoratus & Terrestrial & $\mathrm{LC}$ & $\checkmark$ & $\checkmark$ & - & 2 \\
\hline & Hemiphyllodactylus typus & Terrestrial & DD & - & - & $\checkmark$ & 1 \\
\hline & Gehyra mutilata & Terrestrial & DD & $\checkmark$ & $\checkmark$ & - & 3 \\
\hline Agamidae & Bronchocela jubata & Arboreal & $\mathrm{LC}$ & $\checkmark$ & $\checkmark$ & $\checkmark$ & 4 \\
\hline Elapidae & Bungarus sp. & Terrestrial & $\mathrm{LC}$ & - & $\checkmark$ & - & 1 \\
\hline
\end{tabular}

LC : Least Concern; VU : Vulnerable; DD : Data deficient; $(*)$ : Endemic IUCN: Internationl Union for Conservational Nature

Table 2. Value of index community of herpetofauna at Ledok Amprong tourism site

\begin{tabular}{ccc}
\hline Index & Index & Status \\
& Value & \\
\hline Dominance & 0.150 & Low \\
Diversity & 2.203 & Medium \\
Fairness & 0.565 & Depressed \\
Species Richness & 3.179 & Medium \\
\hline
\end{tabular}

Table 3. Herpetofauna diversity index at Ledok Amprong tourist site based on different zone

\begin{tabular}{lcccccc}
\hline \multicolumn{1}{c}{ Diversity Index by Zone } & \multicolumn{3}{c}{ Species Richness } & \multicolumn{3}{c}{ Species Diversity } \\
\cline { 2 - 7 } & $\mathrm{N}$ & $\mathrm{R} 1$ & $\mathrm{~S}$ & $\mathrm{H}$ & $\mathrm{E}$ & $\mathrm{D}$ \\
\hline $\begin{array}{l}\text { Zone 1 (the area around the park, cottage, } \\
\text { stalls and walkways) }\end{array}$ & 42 & 2.14 & 9 & 1.776 & 0.655 & 0.2234 \\
$\begin{array}{l}\text { Zone 2 (right-left bank of the river and } \\
\text { inside the river) }\end{array}$ & 28 & 1.501 & 6 & 1.359 & 0.648 & 0.3444 \\
Zone 3 (around the watercress fields) & 42 & 2.14 & 9 & 1.121 & 0.374 & 0.493 \\
\hline
\end{tabular}

N: the number of individuals of all types; R1: Margalef's Species richness index; S: number of species found; H ': ShanonWeiner's diversity index; E: Simpson's fairness index, D: Dominance

Table 4. Herpetofauna frequency at Ledok Amprong tourism site

\begin{tabular}{|c|c|c|c|c|c|c|c|c|c|c|}
\hline \multirow{3}{*}{ Family } & \multirow[t]{3}{*}{ Herpetofauna } & \multicolumn{9}{|c|}{ Zone } \\
\hline & & \multicolumn{3}{|c|}{$\begin{array}{l}\text { Zone } 1 \text { (the area around } \\
\text { the park, cottage, stalls } \\
\text { and walkways) }\end{array}$} & \multicolumn{3}{|c|}{$\begin{array}{l}\text { Zone } 2 \text { (right-left } \\
\text { bank of the river and } \\
\text { inside the river) }\end{array}$} & \multicolumn{3}{|c|}{$\begin{array}{l}\text { Zone } 3 \text { (around the } \\
\text { watercress fields) }\end{array}$} \\
\hline & & $\sum \mathrm{i}$ & $\mathrm{F}$ & FR (\%) & $\sum \mathrm{i}$ & $\mathrm{F}$ & FR\% & $\sum \mathrm{i}$ & $\mathrm{F}$ & FR \% \\
\hline Bufonidae & Duttaphrynus melanostictus & 16 & 5.3333 & 38.095 & 1 & 0.333 & 3.571 & 0 & 0 & 0 \\
\hline \multirow{4}{*}{$\begin{array}{l}\text { Rhacoporidae } \\
\text { Ranidae }\end{array}$} & Polypedates leucomystax & 5 & 1.6667 & 11.905 & 1 & 0.333 & 3.571 & 1 & 0.333 & 2.381 \\
\hline & Chalcorona chalcolnota & 4 & 1.3333 & 9.5238 & 15 & 5 & 53.57 & 4 & 1.333 & 9.528 \\
\hline & Huia masonii & 2 & 0.6667 & 4.7619 & 5 & 1.667 & 17.86 & 0 & 0 & 0 \\
\hline & Odorrana hosii & 0 & 0 & 0 & 3 & 1 & 10.71 & 0 & 0 & 0 \\
\hline \multirow[t]{2}{*}{ Dicroglossidae } & Fejervarya limnocharis & 0 & 0 & 0 & 0 & 0 & 0 & 1 & 0.333 & 2,381 \\
\hline & Occydoziga lima & 0 & 0 & 0 & 0 & 0 & 0 & 29 & 9.667 & 69.048 \\
\hline Megophrydae & Leptobrachium haseltii & 0 & 0 & 0 & 0 & 0 & 0 & 1 & 0.333 & 2.381 \\
\hline Microhylidae & Microhyla achatina & 1 & 0.3333 & 2.381 & 0 & 0 & 0 & 0 & 0 & 0 \\
\hline Scincidae & Eutropis multifastiata & 1 & 0.3333 & 2.381 & 0 & 0 & 0 & 2 & 0.667 & 4.7619 \\
\hline \multirow[t]{4}{*}{ Gekkonidae } & Hemidactylus frenatus & 9 & 3 & 21.429 & 0 & 0 & 0 & 0 & 0 & 0 \\
\hline & Cyrtodactylus marmoratus & 0 & 0 & 0 & 0 & 0 & 0 & 2 & 0.667 & 4.7619 \\
\hline & Hemiphyllodactylus typus & 1 & 0.3333 & 2.381 & 0 & 0 & 0 & 0 & 0 & 0 \\
\hline & Gehyra mutilata & 3 & 1 & 7.1429 & 0 & 0 & 0 & 0 & 0 & 0 \\
\hline
\end{tabular}




\begin{tabular}{|c|c|c|c|c|c|c|c|c|c|c|}
\hline Agamidae & Bronchocela jubata & 0 & 0 & 0 & 3 & 1 & 10.71 & 1 & 0.333 & 2.381 \\
\hline Elapidae & Bungarus sp. & 0 & 0 & 0 & 0 & 0 & 0 & 1 & 0.333 & 2.381 \\
\hline & $\sum$ TOTAL & & 14 & 100 & & 9.333 & 100 & & 14 & 100 \\
\hline
\end{tabular}

4) showed that in the first zone most commonly found was Duttaphrynus melanostictus with a value of $38.095 \%$, while the second zone was Chalcorana chalconota type with a relative frequency value of $53.57 \%$, and third zone was Occydoziga lima with a relative frequency value of $69.048 \%$.

Abiotic factors and obtaining sampling results. Based on the data obtained, different results of each sampling from Sampling I, II and III were obtained. This can be caused by external and internal factors such as temperature, humidity and human effort.

Table 5. The physical parameters for each sampling

\begin{tabular}{lccc}
\hline \multirow{2}{*}{ Parameter } & \multicolumn{3}{c}{ Sampling } \\
\cline { 2 - 4 } & 1 & 2 & 3 \\
\hline Air temperature $\left({ }^{0} \mathrm{C}\right)$ & $21^{0} \mathrm{C}$ & $20^{0} \mathrm{C}$ & $23^{0} \mathrm{C}$ \\
Water temperature $\left({ }^{0} \mathrm{C}\right)$ & $20^{0} \mathrm{C}$ & $19^{0} \mathrm{C}$ & $19^{0} \mathrm{C}$ \\
Humidity & $87 \%$ & $86 \%$ & $97 \%$ \\
\hline
\end{tabular}

The temperature obtained in Sampling I, II, and III was relatively similar every month because the sampling was done in the rainy season (Table 5). Air temperature was $21^{\circ} \mathrm{C}$, $20^{\circ} \mathrm{C}, 23^{\circ} \mathrm{C}$. While the water temperature was relatively cool and stable. In accordance with Berry's statement [12] that the optimal temperature for amphibians to live is in the range $26-33^{\circ} \mathrm{C}$ but different in other types. Based on the life needs of reptiles, as proposed by Van Hoeve [13] that reptiles engage in a wider range of temperatures between $20-40^{\circ} \mathrm{C}$. Herpetofauna is also classified as a poikilothermic animal in which body temperature fluctuates, adjusting to ambient temperature. This difference in temperature adjustment causes the specific differences in each species. During rainy season, the frequency of masking and reproducing activities will increase significantly so that herpetofauna easier to find [14].

The humidity obtained in Sampling I, II, III was $86 \%, 87 \%$, and $97 \%$, respectively (Table 5) because in the $3^{\text {rd }}$ Sampling had just rained. This was a sign that the humidity value was very high. A humid place is an ideal place to live for herpetofauna especially amphibians. Iskandar [8] states that an Anura generally lives in a humid forested area due to its skin's need for breathing. Inger [15] explains that high humidity occurs because of the thick canopy of trees that block the sun from penetrating vegetation, so amphibians can live.

Differences in the obtaining the data, were also influenced by effort wherein the first sampling, there was not enough members in sampling, whereas in sampling II and III, sampling member was sufficient. In accordance with Kusrini [7], the calculation of effort is based on the length of search time, the area of the surveyed area, and the seriousness of the members.

Environmental factors may affect the presence of herpetofauna. According to Qurniawan [16], environmental factors have a great role to play in the presence of reptiles and amphibians, especially the landscape, slope, geographical link in the fulfillment of food needs for herpetofauna. While the climate, ,precipitation, temperature, and humidity are influential in creating an appropriate atmosphere for this residence.

Characteristics of microhabitat and species indicators. The composition of herpetofauna species obtained varies widely, proving that the habitat types in the Ledok Amprong were complex (Table 1). Reptile and amphibian habitat types can be divided into several types including terrestrial, arboreal, aquatic, semi-aquatic and fossorial [19].

Zone 1 was categorized as an area dominated by artificial gardens, pavilion, stalls, walkways and other permanent buildings. The dominating species were from the Family of Bufonidae, the Duttaphrynus melanostictus species which was widely distributed and abundant (16 individuals), found under rock basins, around footpaths and permanent buildings. Other species found, from the Family of Gekkonidae, Hemidactylus frenatus (nine individuals) and Gehyra mutilata (three individuals) were found attaching to walls of semi-permanent building or huts that were rarely used. It was also found from the Family of Microhylidae, a species of Microhyla achatina species (one individual) found in a pool of water under Ficus sp. near the Pendopo area. 


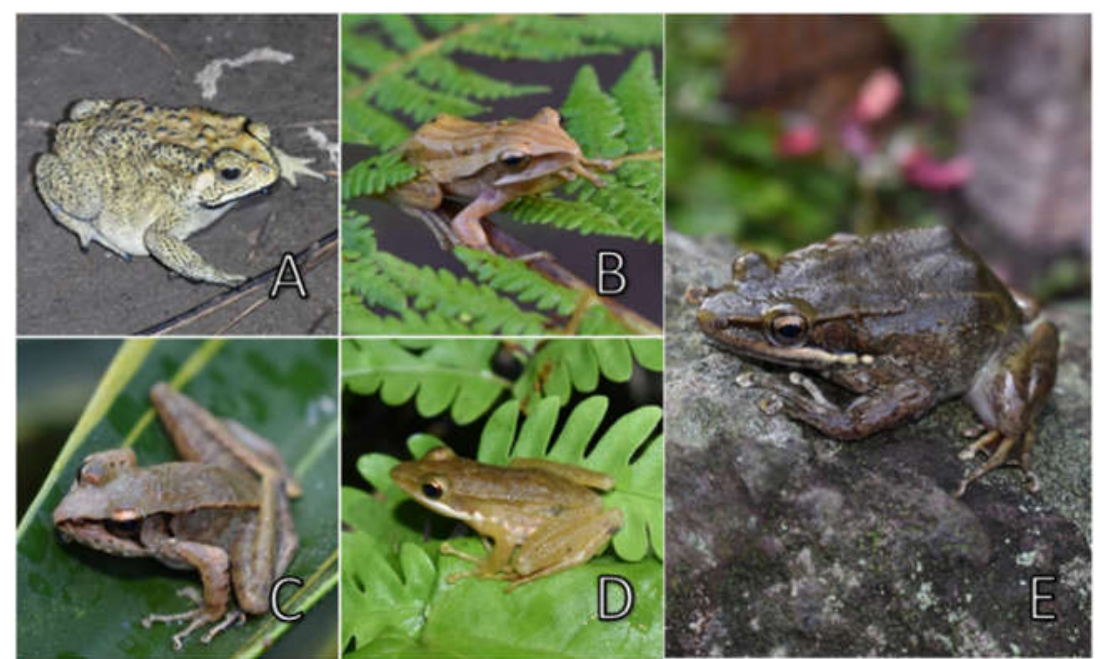

Figure 2. Documentation of the amphibian species encountered (a) Duttaphrynus melanostictus, (b) Polypedates leucomystax, (c) Huia masonii, (d) Chalcorana chalconota and (e) Odorrana hosii

From the Family of Scincidae, species of Eutrophis multifasciata (one individual) were found in the garden area dominated by grasses. In arboreal habitat types, a frogs which are often found in disturbed environments from the Family of Rhacoporidae was a species of Polypedates leucomystax (five individuals) being attached to a plant fern plant (Pteridophyta) and usually puts eggs in wooden basins in tree holes [8]. The existence of Huia masonii species (two individuals) which tended to be in the clear-flowing river flow, and the presence of Chalcorana chalconota (four individuals) who have a preference for waterflow habitats, were not in accordance with the existence of habitat types in Zone 1 [19]. This incompatibility can be due to the need for foraging and finding a mating pair that requires this species to explore further area. All species, found in the air temperature range of $21-23^{\circ} \mathrm{C}$ with high humidity (87$97 \%$ ). The presence of D. melanostictus and $P$. leucomystax that were abundant, can be used as indicators species for the disturbed environment due to better adaptation mechanisms than other amphibian species, so as to dominate and be able to survive better in disturbed environments [20].

Zone 2 was categorized as an area including water flow, right-left edge of water bodies that have been used for sand mining and planted with coniferous plants. This zone supports the existence of aquatic, semiaquatic, arboreal and terrestrial habitat types for herpetofauna. All species were found in an area with the air temperature range of $21-23^{\circ} \mathrm{C}$ and water temperature of $19-20^{\circ} \mathrm{C}$ with high humidity $(87-97 \%)$. Species was found predominate in Zone 2 from the Family of Ranidae, with species of $C$. chalonota (15 individuals) which were often found resting on rocks near the stream of water and taro leaves (Colocasia sp.) on the left/righrt of the water bodies. Duttaphrynus melanostictus (1 individual) was also found on the right of a water body that dominated by herbaceous plants and was found on the forest floor, also $P$. leucomystax species (one individual) was found attaching to a fairly high base daunt of $\pm 1.5 \mathrm{~m}$. Species of the Family of Agamidae that were often encountered, a species of Bronchocela jubata (three individuals) were also found resting on coniferous young trees. In accordance with Qurniawan [21], types of reptiles such as $B$. jubata were classified as animals with arboreal habitat types that were susceptible to the dominance of other introduced species, such as Caloter versicolor species found in Southeast Asia and possibly can shift populations from other Agamidae families. Interestingly, there were few Javanese endemic frog species, namely $H$. masonii (five individuals) and Odorrana hosii (three individuals) who were often found resting on the bank and also herbaceous plants along the river, but not on the forest floor. The species can be used as a indicator species for environmental changes. $H$. masonii has a special adaptation at tadpole phase, which has a suction (abdominal sucker) which is useful for attaching itself to rock that flows rapidly 


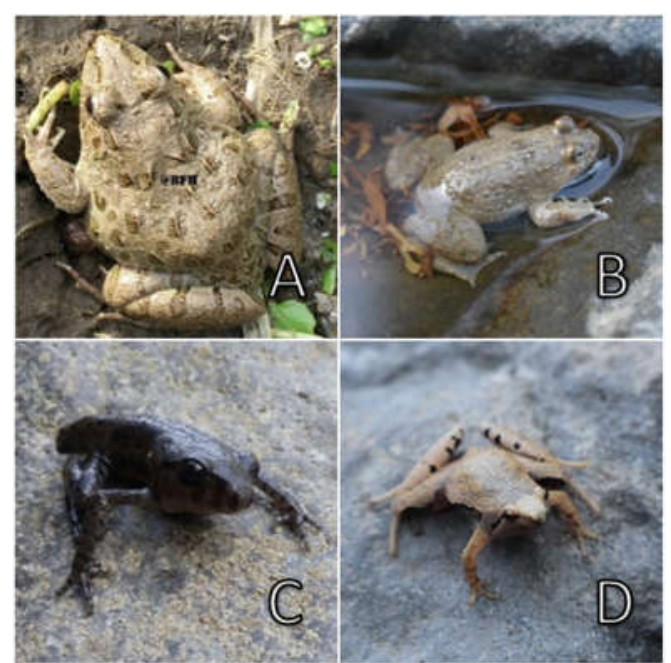

Figure 3. Documentation of the amphibian species encountered, (a) Fejervarya limnocharis, (b) Occidozyga lima, (c) Leptobrachium haseltii, and (d) Microhyla achatina

in a clear, clean waterflow. While $O$. hossi, its existence was always related to rivers in primary and secondary forests and depends on good water quality. In aquatic habitats species were generally found such as Limnonectes sp. (Fanged Frogs) which usually occupies a clean flow, and was not found in Zone 2 [22]. It is indicated that there was a disturbance in the environment by other chemical pollution caused by agricultural activities in the upstream of this region, so amphibian species that have higher adaptability are able to survive in disturbed environments as well as the presence of $C$. chalconota. Although it looks scenery, the Ledok Amprong river flow has been disrupted by the presence of watercress fields and human activities. The absence of limiting human occupancy with rocky, dense and humid natural vegetation causes the herpetofauna population with semiaquatic habitat types to decline [23].

Zone 3 is an area of watercress farm that is flowed directly from the river. This zone supports the existence of herpetofauna species with arboreal, aquatic and terrestrial habitat types. All species were found in the area with air temperature range of $21-23^{\circ} \mathrm{C}$ and water temperature of $19-20^{\circ} \mathrm{C}$ with high humidity (87-97\%). The Family of Rhacoporidae, $P$. leucomystax species (one individual) was found on small tree branches with a height of $\pm 2 \mathrm{~m}$ around rice field trenches. Snakes also found from the Family of Elapidae, a species of Bungarus sp. (one individual) that pass through in the middle of watercress fields, but cannot be captured and identified further. Species of the Family of Agamidae was also found, such as $B$. jubata (one individual) perched on large trees with a height of $\pm 5 \mathrm{~m}$, and herpetofauna species with terrestrial habitat types, such as E. multifasciata (two individuals) and Cyrtodactylus marmoratus (two individuals) were also found which were perched under rock basins to basking. A species of $C$. chalconota (four individuals) were also found in watercress fields which were directly adjacent to the water body, found to be attached to the leaves of taro (Colocasia sp.) and rocks by water bodies. Occidozyga lima species from the Family of Dicroglossidae was also found which was usually found in the watercress field trenches, and sometimes in the midst of watercress fields that can be characterized by the sounds that are heard day or night and can be seen with the body submerged with eyes above the water surface [8]. The presence of Occidozyga lima populations (29 individuals) that were abundant in watercress fields or wetlands was usually followed by a population of other frog species such as Fejervarya limnocharis and Fejervarya cancrivora, but the results of the sampling were found, $F$. limnocharis with a very little population (one individual). The abundant species of $O$. lima dominated the watercress fields of Zone 3. But to prove this, further sampling is needed with a larger search area. Another interesting thing was the presence of Leptobrachium hasseltii (one individual) which was only found in the juvenile phase in the trenches around the watercress field, burrowing and covered with litter. The frog from Family of Megophrydae, has perfect camouflage and has legs that are shorter than its arms so it cannot avoid predators. This species can be used as an environmental bioindicator because its characteristics that are very sensitive to the presence of chemical compounds contained in the water flow, especially at the larval phase [24].

One of the other interesting discoveries was the Hemiphyllodactylus typus species found in the Zone 3 area with only one individual, attached to a wooden fence that limits watercress fields and buildings. This small gecko species has a prehensile tail with a pale dorsum with various shades, and 

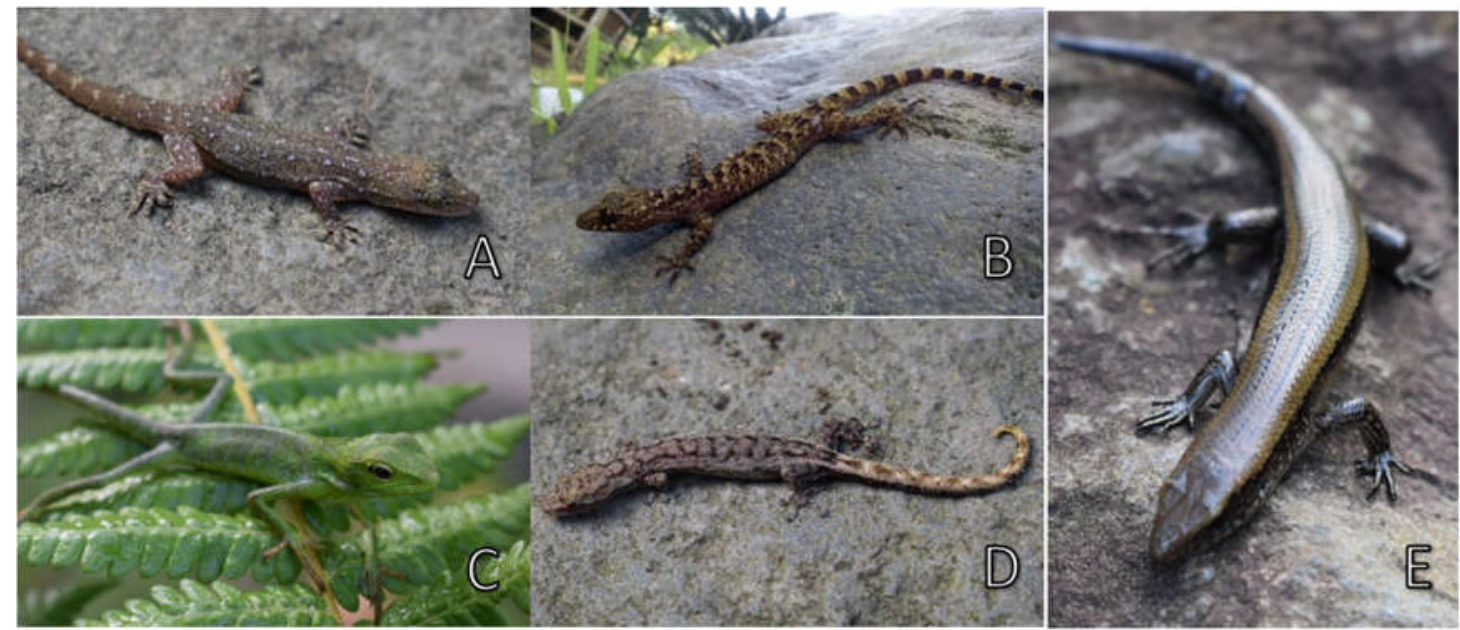

Figure 4. Documentation of the reptile species encountered, (a) Cyrtodactylus marmoratus, (b) Hemidactylus typus, (c) Bronchocela jubata, (d) Hemiphyllodactylus typus, and (e) Eutropis multifasciata

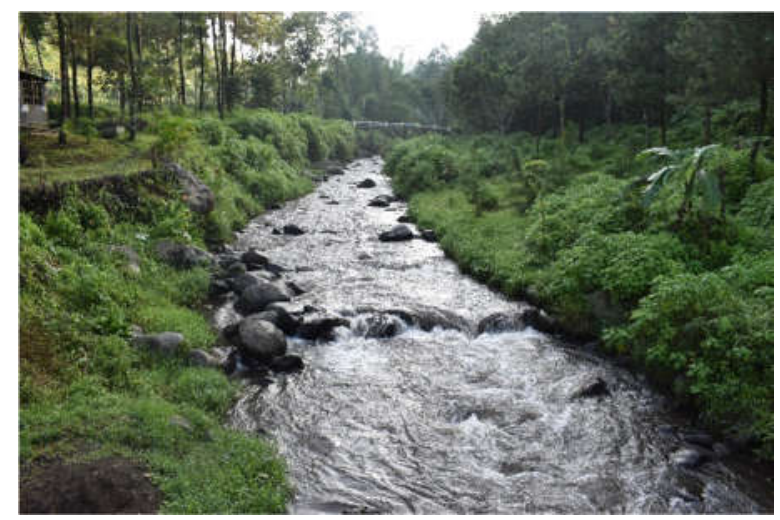

Figure 5. The Situation of waterflow in Ledok Amprong

ventral and subcaudal colors (distinct). This species prefers open forest areas and usually attaches to large leaves, including shrubs and small trees [25]. According to Zug [26], Lizards from the Genus Hemiphyllodactylus is rarely found. This species is classified as both unisexual (H. typus) and bisexual (other species) species where the reproductive type is isolated by a geographical barrier. This species is widely distributed including India, Southeast Asia, Papua New Guinea, and several other Pacific Islands. The possibility of this species is accidentally distributed through human transportation. The existence of this species adds to the diversity data in the Ledok Amprong Nature tourism, because of its presence which is rarely found and is very interesting to be studied further.

\section{CONCLUSION}

The number of reptiles and amphibians found in the Ledok Amprong, among them from the Squamata Order was seven species consisting of the Gekkonidae Family, Scincidae, Agamidae, and Elapidae. While from the Anura Order, found as many as nine species consisting of Family Bufonidae, Ranidae, Rhacophoridae, Dicroglossidae, and Microhylidae. Ledok Amprong has a complex ecosystem, composed of reptiles and amphibians that live in four types of habitats such as terrestrial, arboreal, semi-aquatic and aquatic. However, the diversity index, relative frequency, and dominance value, also indicator species for disturbed environment indicated that this area has relatively low biodiversity, disturbed environment and conservation efforts need to be undertaken.

\section{REFERENCES}

[1] Pemkab Kabupaten Malang, 2016. Selayang Pandang. http://www.malangkab.go.id/site/read/de tail/79/selayang-pandang.html Accesed on 27 January 2018.

[2] Sylviani, 2008. Kajian Distribusi Biaya Dan Manfaat Hutan Lindung Sebagai Pengatur Tata Air. Jurnal Penelitian Sosial dan Ekonomi Kehutanan. 5 (2): $95-109$.

[3] Das, Indraneil. 2015. A field guide to the reptiles of Southeast Asia. Bloomsbury Publishing, London.

[4] Primack, Richard B., Jatna Supriatna, M. Indrawan dan P. Kramadibrata, 1998. Biologi konservasi. Yayasan Obor Indonesia, Jakarta.

[5] Jaeger, R. G., 1994. Transect Sampling in Measuring dan Monitoring Biological Diversity Standard Methods for 
Amphibians. Smithsonian Institution Press, Washington.

[6] Crump, M. L., and N.J. Scott., 1994. Visual Encounter Surveys in Measuring dan Monitoring Biological Diversity Standard Methods for Amphibians. Smithsonian Institution Press. Washington.

[7] Kusrini M.D., 2008. Pedoman Penelitian Dan Survey Amfibi Di Alam. Fakultas Kehutanan, IPB Bogor.

[8] Iskandar, D.T., 1998. Amfibi Jawa dan Bali: Seri Panduan Lapangan, Cetakan pertama. Puslitbang Biologi-LIPI, Bogor.

[9] Kurniati, H., 2003. Amphibians and reptiles of Gunung Halimun National Park, West Java, Indonesia. Research Center for Biology-LIPI, Cibinong.

[10] Van Kampen, P.N, 1923. The Amphibia of the Indo-Australian Archipelago. E. J. Brill Ltd, Leiden.

[11] Odum E.P., 1993. Dasar-dasar Ekologi, Edisi Ketiga. Universitas Gajah Mada, Yogyakarta.

[12] Berry, 1975. The Amphibian Fauna of Peninsular Malaysia. Tropical Pr, Kuala Lumpur.

[13] Van Hoeve, B.V.U.W., 1992. Ensiklopedi Indonesia Seri Fauna: Reptilia dan Amfibia. Ichtiar Baru, Jakarta.

[14] Zug, G.R. 1993. Herpetology: An Introductory Biology of Amphibians and Reptiles. Academic Press, San Diego California.

[15] Inger RF. 1966. The Systematics and Zoogeography of The Amphibia of Borneo. Field Museum of Natural History. Chicago.

[16] Qurniawan, T.F., Addien F.U., Eprilurahman, R., dan Trijoko, 2002. Eksplorasi Keanekaragaman Herpetofaunna Di Kecamatan Girimulyo Kabupaten Kulon Progo Yogyakarta. Jurnal Teknosains, 1 (22): 71-143.

[17] Hill, D. Fasham, M. Tucker, G. Shewry, M. dan Shaw, P. 2005. Handbook of Biodiversity Methods, Survey, Evaluation and Monitoring. Cambridge Unversity Press, New York.

[18] Krebs, C. J., 1985. Ecology Experimental Analysis of Distribution Abudance. Harper \& Row Publisher, Philadelphia.
[19] Mistar, 2003. Panduan Lapangan Amfibi Kawasan Ekosistem Leuser. Bogor: The Gibbon Foundation \& PILI-NGO Movement.

http://d.yimg.com/kq/groups/23403542/ 1688751700/name/metodherpet.doc.

Accesed on 27 January, 2017.

[20] Mumpuni, M., 2001. Keanekaragaman Herpetofauna Di Taman Nasional Gunung Halimun, Jawa Barat. Berita Biologi, 5 (6).

[21] Qurniawan, T.F., \& Eprilurahman, R., 2012. Keanekaragaman Jenis Herpetofauna di Kawasan Ekowisata Goa Kiskendo, Kulonprogo, Provinsi Daerah Istimewa Yogyakarta. Biota, 17 (2): $78-84$

[22] Yani, A., \& Said, S., 2015. Keanekaragaman Jenis Amfibi Ordo Anura di Kawasan Hutan Lindung Gunung Semahung Kecamatan Sengah Temila Kabupaten Landak Kalimantan Barat. Jurnal Hutan Lestari, 3 (1).

[23] Yudha, D. S., Eprilurahman, R., Trijoko, T., Alawi, M. F., \& Tarekat, A. A., 2014. Keanekaragaman Jenis Katak dan Kodok (Ordo Anura) di Sepanjang Sungai Opak, Propinsi Daerah Istimewa Yogyakarta. Jurnal Biologi, 18 (2): 5259.

[24] Triesita, N. I. P., Pratama, M. Y. A., Pahlevi, I., Jamaluddin, M. A., Hanifa, B. F., 2017. Komposisi Amfibi Ordo Anura di Kawasan Wisata Air Terjun Ironggolo Kediri Sebagai Bio Indikator Alami Pencemaran Lingkungan. Prosiding Semnas Hayati JV: 46-52.

[25] Lizard of Souetheast Asia: Lowland Dwarf Gecko. 2018.

https://www.ecologyasia.com/verts/lizar ds/lowland-dwarf gecko.html. Accessed on 9 Agustus 2018.

[26] Zug, G. R., 2010. Speciation and dispersal in a low diversity taxon: The Slender Geckos Hemiphyllodactylus (Reptilia, Gekkonidae). Smithsonian Contributions to Zoology: XXI-70. 